\title{
SPK Penentuan Lokasi ATM Menggunakan Metode AHP dan SAW
}

\author{
Gede Surya Mahendra ${ }^{a}$, Kadek Yota Ernanda Aryanto ${ }^{b}$ \\ ${ }^{a}$ Program Studi Teknik Informatika, STIMIK STIKOM Indonesia, Jl Tukad Pakerisan No 97 Denpasar 80225, Indonesia \\ ${ }^{b}$ Program Studi Ilmu Komputer, Program Pascasarjana, Universitas Pendidikan Ganesha, Jl. Udayana, Singaraja, Bali 81116, Indonesia
}

\section{INFORMASI ARTIKEL}

Sejarah Artikel:

Diterima Redaksi: 31 Oktober 2018

Revisi Akhir: 17 Januari 2019

Diterbitkan Online: 30 April 2019

\section{KATA KUNCI}

\begin{tabular}{l}
\hline AHP \\
ATM \\
SAW \\
SPK \\
KORESPONDENSI \\
\hline
\end{tabular}

Telepon: +62 (0361) 256995

E-mail: gede.mahendra@stiki-indonesia.ac.id

\section{A B $\mathbf{S}$ T $\mathbf{R}$ A $\mathbf{C}$ T}

Persaingan industri perbankan saat ini semakin meningkat, baik dalam hal penyediaan inovasi produk serta peningkatan kualitas transaksi dan pelayanan. Untuk mengatasi masalah tersebut diciptakan sebuah terminal yang dikenal dengan ATM. Namun fungsionalitas dan efektifitas ATM tersebut belum memenuhi kebutuhan nasabah dikarenakan pengambilan keputusan penentuan lokasi ATM belum menggunakan SPK sehingga banyak kriteria yang terlupakan dalam penentuan lokasi ATM terbaik. Metode AHP yang merupakan sebuah hierarki fungsional dengan input utamanya adalah persepsi manusia sedangkan metode SAW dengan konsep dasar mencari penjumlahan terbobot dari rating kinerja pada setiap alternatif pada semua atribut. AHP digunakan untuk memberikan pembobotan pada masing-masing kriteria dan SAW untuk melakukan perangkingan dari masing-masing alternatif. Terdapat 7 kriteria dengan 11 sub kriteria pada pembobotan dan 76 data alternatif. Pengujian dilakukan dengan membandingkan hasil delpoyment ATM dengan hasil perhitungan sistem. Dari 76 data alternatif yang diujikan, terdapat 38 lokasi deployment ATM. Dari hasil pengujian yang ditampilkan dalam confusion matrix, pada kriteria yang tidak teruji signifikansi didapatkan 33 data True Positive, 38 True Negative, 5 False Negative dan 5 False Positive dengan akurasi sebesar 86,84\%, dan pada kriteria yang teruji signifikansi didapatkan 35 data True Positive, 35 True Negative, 3 False Negative dan 3 False Positive memiliki akurasi 92,11\%.

\section{PENDAHULUAN}

Melambatnya pertumbuhan ekonomi nasional tahun 2015, telah menggeser arah pertumbuhan ekonomi ke arah timur, khususnya di kawasan Bali dan Nusa Tenggara yang telah mencapai pertumbuhan ekonomi yang luar biasa di akhir tahun 2015 [1]. Bali dan Nusa Tenggara tercatat sebagai kawasan yang memiliki pertumbuhan tahunan Produk Domestik Bruto (PDB) tertinggi secara nasional sebesar 10,3\%, dengan kontribusi pertumbuhan terhadap perekonomian nasional sebesar $3,1 \%$.

Persaingan industri perbankan saat ini semakin meningkat, baik dalam hal penyediaan inovasi produk serta peningkatan kualitas transaksi dan pelayanan. Bank harus mencari cara untuk dapat bersaing dan juga memberikan pelayanan perbankan prima kepada nasabah, salah satunya dengan dukungan teknologi informasi, salah satunya dengan Automatic Teller Machine (ATM).

Saat ini penempatan lokasi ATM biasanya ditempat keramaian, unit bank dan wilayah institusi yang bekerjasama dengan pihak bank. Permasalahan yang dihadapi perbankan dalam penempatan lokasi ATM salah satunya adalah vandalisme terhadap ATM, yang berdampak pada kerugian dari pihak bank. Vandalisme berdampak pada kerusakan mesin ATM, bangunan dan kelengkapannya sehingga menyebabkan in-service dari ATM tidak dapat berlangsung secara optimal, sehingga beresiko menurunkan usage, performance, dan income ATM. Selain itu, maraknya kasus card skimming (card cloning), dapat mengakibatkan kerugian materi dan kerugian integeritas bagi pihak bank. Pada tahun 2015, Direktorat Tindak Pidana Ekonomi dan Khusus Bareskrim POLRI sudah mencatat terdapat 1.549 kasus, yang membuat sepertiga kasus skimming di dunia terjadi di Indonesia, menyebabkan keamanan transaksi menggunakan ATM merupakan prioritas dari pelayanan perbankan [2].

Penempatan lokasi ATM yang tepat, selain dapat mengurangi kemungkinan terjadinya vandalisme dan card skimming, juga mampu menjadi kesempatan bank untuk berinovasi dalam persaingan perbankan global melalui pengembangan teknologi ATM, penerapan produk dan layanan perbankan terbaru, peningkatan ekspansi pasar secara global dan mampu meningkatkan kerjasama antar negara, yang akan berdampak positif terhadap laba yang akan diperoleh pihak bank.

Sistem Pendukung Keputusan merupakan sebuah sistem yang efektif dalam membantu mengambil suatu keputusan yang kompleks, sistem ini menggunakan aturan-aturan pengambilan 
keputusan, model analisis, database yang komprehensif dan pengetahuan dari pengambil keputusan itu sendiri [3]. Metode Analytic Hierarchy Process (AHP) yang merupakan sebuah hierarki fungsional dengan input utamanya adalah persepsi manusia, sedangkan metode Simple Additive Weighting (SAW) dengan konsep dasar mencari penjumlahan terbobot dari rating kinerja pada setiap alternatif pada semua atribut[4]. Keuntungan metode AHP dan SAW dibandingkan dengan metode lainnya adalah karena metode AHP didesain untuk membantu pengambil keputusan untuk menggabungkan faktor kualitatif dan faktor kuantitatif dari suatu permasalahan yang kompleks dan dapat menghasilkan solusi dari berbagai faktor yang saling bertentangan. Di lain sisi, metode SAW memiliki keuntungan berupa urutan relatif dari besarnya nilai standar tetap sama[5].

Tantangan dalam SPK penentuan lokasi ATM menggunakan AHP dan SAW ini adalah memberikan menjadi acuan dasar dalam penentuan lokasi ATM untuk memberikan rekomendasi yang tepat bagi perbankan untuk penentuan lokasi ATM yang dekat, aman, nyaman bagi nasabah. Dengan memanfaatkan penggunaan teknologi komputer, dapat dikembangkan suatu sistem yang dapat memberikan masukkan dalam menentukan lokasi yang sesuai untuk penentuan lokasi ATM, dimana faktorfaktor yang mendukung tidak lepas dari kondisi geografis dari daerah tersebut, kondisi masyarakat dari daerah tersebut perkembangan dari pemanfaatan teknologi dan perkembangan infrastruktur lokasi yang akan digunakan sebagai lokasi ATM. Tujuan penelitian ini adalah untuk merancang, mengimplementasikan, dan menganalisis hasil dari sistem pendukung keputusan penentuan lokasi ATM menggunakan AHP dan SAW.

\subsection{Automated Teller Machine (ATM)}

Automated Teller Machine (ATM) adalah "alat telekomunikasi berbasis komputer yang menyediakan tempat bagi nasabah dalam melakukan transaksi keuangan tanpa membutuhkan seorang teller bank." ATM dalam bahasa asing Automated Teller Machine dan dalam bahasa Indonesia Anjungan Tunai Mandiri. ATM dikembangkan oleh Luther George Simjian tahun 1939 di City Bank, di New York. Terdapat 5 kepuasan yang dapat dirasakan nasabah bila bertransaksi melalui ATM berupa kemudahan penggunaan jasa perbankan, keleluasaan waktu pelayanan, kecepatan dan ketepatan pelayanan, keamanan pelayanan serta keanekaragaman jenis pelayanan.

Secara umum fungsi ATM adalah agar dapat melakukan penarikan uang tunai, serta mempermudah kepentingan nasabah dalam melakukan aktivitas perbankan, seperti informasi saldo, pembayaran umum (tagihan telepon, kartu kredit, listrik, air, handphone, dan uang kuliah), pembelian, tiket penerbangan, isi ulang pulsa, pemindahbukuan (open transfer), serta Pengubahan PIN.

Di Indonesia ATM baru marak dikenal sekitar sepuluh tahun yang lalu, dengan latar pembentukan ATM ini dilakukan oleh sektor perbankan yang bertujuan untuk meningkatkan pelayanan, menunjang bisnis riteil, menghadapi teknologi informasi perbankan antar bank, memehuni kebutuhan masyarakat dan keterbatasan jarak dan waktu, serta sebagai sarana promosi perbankan.
Selain itu manfaat yang dapat dirasakan oleh nasabah dari pelayanan ATM tersebut adalah nasabah dapat melakukan pelayanan sendiri, melakukan transaksi perbankan tunai maupun non tunai tanpa harus mendatangi kantor cabang yang dituju, melakukan transaksi perbankan tanpa dibatasi waktu dan tempat, karena layanan ATM on-line selama 24 jam, serta tidak perlu menyimpan uang kas terlalu banyak.

Manfaat ATM bagi pihak bank sendiri adalah pihak bank mampu menarik nasabah baru yang lebih banyak untuk menabung dan meningkatkan pendapatan, mendorong nasabah agar lebih aktif menggunakan jasa perbankan mengurangi antrian nasabah di Kantor Cabang, membuka peluang munculnya produk dan jasa baru, sebagai media promosi serta mengoptimalkan jaringan komunikasi yang ada.

\subsection{Kriteria dan Sub Kriteria pada Penentuan Lokasi ATM}

Dari beberapa penelitian yang telah dilakukan sebelumnya serta hasil dari wawancara dengan ahli, dapat dirangkum beberapa variabel yang akan digunakan sebagai kriteria dan sub kriteria. Kriteria dan sub kriteria yang digunakan adalah bersifat independen dan dikerjakan secara hirarki berdaasrkan metode AHP. Terdapat 7 kriteria dan sub kriteria dalam penelitian ini, yaitu Ketersediaan ATM, ATM kompetitor, kemananan, harga lahan, permintaan nasabah, kondisi gedung, dan jarak dari pusat keramaian. Kriteria kondisi gedung, memiliki 4 sub kriteria, yaitu kondisi bangunan, akses lokasi, lahan parkir, serta instalasi listrik dan jaringan internet. Kriteria jarak dari pusat keramaian, memiliki 8 sub kriteria yaitu jarak dengan pusat perbelanjaan, jarak dengan objek wisata, jarak dengan hotel/ restoran, jarak dengan rumah sakit, jarak dengan SPBU, jarak dengan perumahan, jarak dengan instansi pemerintah/ swasta, serta jarak dengan sekolah/ perguruan tinggi.

Uji signifikansi dilakukan untuk mengetahui apakah taksiran parameter berpengaruh berpengaruh terhadap model atau tidak secara signifikan, serta mengetahui seberapa besar pengaruh masing-masing parameter tersebut. Uji signifikansi dapat dilakukan salah satunya dengan cara analisis regresi. Analisis regresi merupakan salah satu teknik analisis data dalam statistika yang seringkali digunakan untuk mengkaji hubungan antara beberapa variabel dan meramal suatu variabel [6].

Multiple-Criteria Decision Making (MCDM) adalah suatu metode pengambilan keputusan untuk menetapkan alternatif terbaik dari sejumlah alternatif berdasarkan beberapa kriteria tertentu [7]. Secara umum dapat dikatakan bahwa MCDM menyeleksi alternatif terbaik dari sejumlah alternatif. Fitur umum yang digunakan dalam MCDM adalah alternatif, atribut/ kriteria keputusan, konflik antar kriteria, bobot keputusan, serta matriks keputusan. Metode Analytic Hierarchy Process (AHP) dan Simple Additive Weighting (SAW) adalah salah satu metode yang dapat digunakan untuk menyelesaikan masalah Fuzzy Multiple Attribute Decision Making (FMADM).

\subsection{Analytic Hierarchy Process (AHP)}

AHP dikembangkan oleh Thomas L. Saaty pada awal tahun 1970. AHP didesain untuk membantu pengambil keputusan untuk menggabungkan faktor kualitatif dan faktor kuantitatif dari suatu 
permasalahan yang kompleks. Penggunaan AHP dalam berbagai bidang meningkat cukup signifikan, hal ini dikarenakan AHP dapat menghasilkan solusi dari berbagai faktor yang saling bertentangan. AHP diaplikasikan dalam bidang agrikultur, sosiologi, industri dan lain sebagainya.

Ada beberapa prinsip dasar dalam menyelesaikan persoalan dengan Metode AHP, yakni decomposition, comparative judgment, synthesis of priority, dan logical consistency. Prinsip decomposition merupakan tindakan memecah persoalanpersoalan yang utuh menjadi unsur-unsurnya, dengan tingkatan berupa goal, kriteria dan alternatif. Prinsip comparative judgment, merupakan penilaian tentang kepentingan relatif dua elemen pada suatu tingkat tertentu dalam kaitannya dengan tingkat yang diatasnya. Penilaian ini merupakan inti dari metode AHP, karena akan berpengaruh terhadap prioritas elemenelemen. Hasil dari penilaian ini disajikan dalam bentuk matriks yang disebut pairwise comparison matrix.

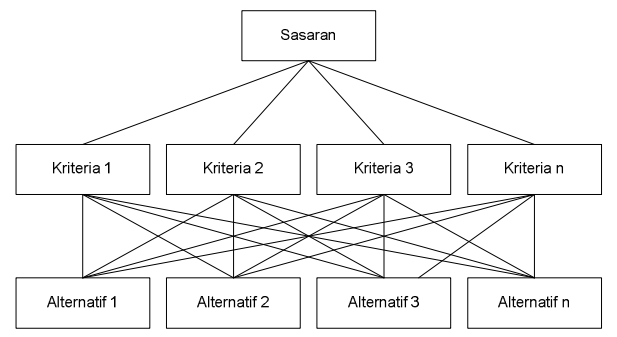

Gambar 1. Dekomposisi pada AHP

Skala yang digunakan untuk menyatakan tingkat preferensi adalah skala Saaty. Setelah pairwise comparison matrix diperoleh, kemudian dicari Eigen vector-nya untuk mendapatkan local priority pada prinsip synthesis of priority. Prinsip logical consistency, menyatakan bahwa konsistensi memiliki dua makna. Pertama adalah bahwa obyek-obyek yang serupa dapat dikelompokkan sesuai dengan keseragaman dan relevansinya. Kedua adalah tingkat hubungan antara obyek-obyek yang didasarkan pada kriteria tertentu.

Algoritma AHP dimulai dari mendefinisikan masalah dan menentukan solusi yang diinginkan, membuat struktur hirarki yang diawali dengan tujuan umum, dilanjutkan dengan kriteriakriteria, sub kriteria dan alternatif-alternatif pilihan yang ingin di ranking, menentukan matriks perbandingan berpasangan tiap kriteria, menormalkan data dengan membagi nilai dari setiap elemen di dalam matriks yang berpasangan dengan nilai total dari setiap kolom, menghitung nilai Eigen vector dan menguji konsistensinya.

Tabel 1. Skala Saaty

\begin{tabular}{ll}
\hline $\begin{array}{l}\text { Tingkat } \\
\text { Kepentingan }\end{array}$ & Definisi \\
\hline $\mathbf{1}$ & Sama pentingnya dibanding yang lain \\
\hline $\mathbf{3}$ & Moderat pentingnya dibanding yang lain \\
\hline $\mathbf{5}$ & Kuat pentingnya dibanding yang lain \\
\hline $\mathbf{7}$ & $\begin{array}{l}\text { Sangat kuat pentingnya dibanding yang } \\
\text { lain }\end{array}$ \\
\hline $\mathbf{9}$ & Ekstrim pentingnya dibanding yang lain \\
\hline
\end{tabular}

\subsection{Simple Additive Weighting (SAW)}

Metode SAW sering juga dikenal istilah metode penjumlahan terbobot. Konsep dasar metode SAW adalah mencari penjumlahan terbobot dari rating kinerja pada setiap alternatif pada semua atribut [3]. Algoritma SAW dilakukan setelah metode AHP dilakukan dan mendapatkan nilai eigen vector yang dimulai dari hasil dari nilai rating kinerja ternormalisasi membentuk matriks ternormalisasi dan melakukan proses perankingan dengan cara mengalikan matriks ternormalisasi dengan nilai bobot preferensi (Eigen vector). Nilai preferensi untuk setiap alternatif dapat ditentukan dengan cara menjumlahkan hasil kali antara matriks ternormalisasi dengan nilai bobot preferensi, dengan nilai preferensi yang lebih besar merupakan alternatif lebih baik.

\subsection{Confusion Matrix}

Confusion Matrix merupakan sebuah metode untuk evaluasi yang menggunakan tabel matriks seperti pada gambar 1. Dataset terdiri dari dua kelas, kelas yang satu dianggap sebagai positif dan yang lainnya negatif [8]. Evaluasi dengan confusion matrix menghasilkan nilai accuracy, precision, dan recall.

Nilai accuracy merupakan persentase jumlah record data yang diklasifikasikan secara benar oleh sebuah algoritma dapat membuat klasifikasi setelah dilakukan pengujian pada hasil klasifikasi tersebut [9]. Nilai precision atau dikenal juga dengan nama confidence merupakan proporsi jumlah kasus yang diprediksi positif yang juga positif benar pada data yang sebenarnya. Sedangkan nilai dari recall atau sensitivity merupakan proporsi jumlah kasus positif yang sebenarnya yang diprediksi positif secara benar. True Positive adalah jumlah record positif yang diklasifikasikan sebagai positif, false positive adalah jumlah record negatif yang diklasifikasikan sebagai positif, false negative adalah jumlah record positif yang diklasifikasikan sebagai negatif, true negative adalah jumlah record negatif yang diklasifikasikan sebagai negatif, kemudian masukkan data uji. Setelah data uji dimasukkan ke dalam confusion matrix, hitung nilai-nilai yang telah dimasukkan tersebut untuk dihitung jumlah sensitivity (recall positive), Specifity (recall negative), precision, dan accuracy. Sensitivity digunakan untuk membandingkan jumlah True Positive (TP) terhadap jumlah record yang positif sedangkan Specifity, precision adalah perbandingan jumlah True Negative (TN) terhadap jumlah record yang negatif.

$T P R=\frac{T P}{P}=\frac{T P}{T P+F N}$

$T N R=\frac{T N}{N}=\frac{T P}{T N+F P}$

$P P V=\frac{T P}{T P+F P}$

$N P V=\frac{T N}{T N+F N}$ 
$A C C=\frac{T P+T N}{P+N}$

$E R R=\frac{F P+F N}{P+N}$

\section{METODOLOGI}

Dalam rangka mengurangi permasalahan yang muncul pada penentuan lokasi ATM dimana menentukan lokasi ATM yang tepat untuk menempatkan mesin ATM, yang diharapkan mampu untuk meningkatkan kualitas pelayanan perbankan, berdaya saing, menghindari vandalisme, card skimming, dan memberikan pihak perbankan untuk berinovasi dalam persaingan perbankan global melalui pengembangan teknologi ATM, penerapan produk dan layanan perbankan terbaru, peningkatan ekspansi pasar secara global dan mampu meningkatkan kerjasama antar negara, yang akan berdampak positif terhadap laba yang akan diperoleh pihak bank.

Berdasarkan analisis masalah tersebut, maka solusi yang dapat diusulkan adalah SPK penentuan lokasi ATM menggunakan AHP dan SAW mengingat pengaruh teknologi informasi dan internet sangat dibutuhkan dalam penentuan lokasi ATM terutama bagi daerah-daerah yang selama ini menjadi pusat perhatian ataupun yang beresiko tinggi. SPK ini melakukan perhitungan dan memberikan rekomendasi terbaik terhadap calon lokasi ATM.

Metode AHP memiliki beberapa keuntungan dibandingkan beberapa metode yang ada. Dalam studi kasus dengan sedikit data, AHP memiliki keuntungan dibandingkan dengan PROMETHEE dan TOPSIS, dimana AHP memberikan hasil yang sama namun kinerjanya lebih cepat dan sederhana sehingga mudah dimengerti [10]. AHP juga dapat diterapkan dengan mudah pada perhitungan berbasis spreadsheet. Kemudian, berdasarkan perbandingan kinerja metode AHP, TOPSIS, dan AHP-TOPSIS, metode AHP menjadi metode rekomendasi terbaik yang dihasilkan dalam penelitiannya [11].

Untuk metode SAW, perbandingan hasil ranking pada SAW dan WP tidak terlihat perbedaan yang signifikan, namun bila dibandingkan dengan data nyata, metode WP memiliki akurasi $85,71 \%$ sedangkan SAW lebih baik yakni mencapai $100 \%$ [12]. Kemudian, metode SAW lebih baik daripada metode WP. waktu eksekusi metode SAW lebih cepat dibandingkan WP, karena proses perhitungan SAW lebih sederhana dibandingkan WP[12], [13].

SPK ini dalam proses pembobotan kriteria dan sub kriteria sesuai dengan tingkat kepentingan dari kriteria yang telah di sediakan, menggunakan 7 kriteria dan 12 sub kriteria. Selanjutnya akan dilakukan perhitungan pada kriteria yang tidak teruji signifikansi dan yang teruji signifikansi dan dibandingkan hasil akurasinya lebih lanjut. Data alternatif pada SPK ini adalah data deployment ATM sebanyak 76 data lokasi ATM pada tahun perencanaan 2017. Penilaian dari masing-masing data lokasi telah dikonsultasikan dengan pihak internal, berdasarkan interpretasi yang ditentukan.
Tabel 2. Kriteria dan Sub Kriteria yang Digunakan

\begin{tabular}{|c|c|c|}
\hline No & $\begin{array}{l}\text { Kode Kriteria / } \\
\text { Sub Kriteria }\end{array}$ & Kriteria / Sub Kriteria \\
\hline 1 & (C1) & Ketersediaan ATM \\
\hline 2 & $(\mathrm{C} 2)$ & ATM kompetitor \\
\hline 3 & (C3) & Keamanan (security) \\
\hline 4 & (C4) & Harga Lahan \\
\hline 5 & (C5) & Permintaan Nasabah \\
\hline 6 & (C6) & Kondisi Gedung \\
\hline 7 & (C7) & Jarak dengan Pusat Keramaian \\
\hline 8 & $(\mathrm{C} 6-\mathrm{SC} 1)$ & Kondisi Bangunan \\
\hline 9 & $(\mathrm{C} 6-\mathrm{SC} 2)$ & Akses Lokasi \\
\hline 10 & $(\mathrm{C} 6-\mathrm{SC} 3)$ & Lahan Parkir \\
\hline 11 & $(\mathrm{C} 6-\mathrm{SC} 4)$ & $\begin{array}{l}\text { Instalasi Listrik dan Jaringan } \\
\text { Internet }\end{array}$ \\
\hline 12 & $(\mathrm{C} 7-\mathrm{SC} 1)$ & Jarak dengan Pusat Perbelanjaan \\
\hline 13 & $(\mathrm{C} 7-\mathrm{SC} 2)$ & Jarak dengan Objek Wisata \\
\hline 14 & $(\mathrm{C} 7-\mathrm{SC} 3)$ & Jarak dengan Hotel / Restoran \\
\hline 15 & $(\mathrm{C} 7-\mathrm{SC} 4)$ & Jarak dengan Rumah Sakit \\
\hline 16 & (C7 - SC5) & Jarak dengan SPBU \\
\hline 17 & (C7 - SC6) & Jarak dengan Perumahan \\
\hline 18 & $(\mathrm{C} 7-\mathrm{SC} 7)$ & $\begin{array}{lcl}\text { Jarak dengan } & \text { Instansi } \\
\text { Pemerintahan/ Swasta } & \end{array}$ \\
\hline 19 & $(\mathrm{C} 7-\mathrm{SC} 8)$ & $\begin{array}{ll}\text { Jarak } & \text { dengan } \\
\text { Perguruan Tinggi }\end{array}$ \\
\hline
\end{tabular}

Hasil wawancara atau kuisioner dari narasumber diterjemahkan dalam matriks perbandingan berpasangan. dengan menggunakan skala Saaty, dan dilakukan normalisasi dengan cara membagi nilai masing-masing alternatif terhadap nilai jumlah dari masingmasing kriteria atau sub kriteria masing-masing, dan setiap kriteria akan di cari rata-ratanya setelah ternormalisasi, dan lakukan pengecekan perhitungan Principal Eigen Value dengan mengalikan jumlah pada hasil dari kolom interpretasi dengan rata-rata perbaris setelah normalisasi. Kemudian dilakukan perhitungan Consistency Index (CI) dengan cara membagi Principal Eigen Value dikurang jumlah kriteria / sub kriteria dengan jumlah kriteria / sub kriteria dikurang 1. Consistency Ratio (CR) didapatkan dari CI dibagi dengan Random Index (RI) sesuai jumlah kriteria / sub kriteria. Bila CR kurang dari 0,10 maka nilai Eigen Vector valid, bila tidak, pembobotan harus di ulang kembali.

Proses pada metode SAW, dengan hasil interpretasi sebelumnya, dapat dihasilkan nilai Sub Kriteria 1 (Kondisi Gedung) dan Sub Kriteria 2 (Jarak dengan Pusat Keramaian), dengan melakukan perkalian matriks antara Eigen vector pada pembobotan Sub Kriteria 1 dan normalisasi dari hasil interpretasi Sub Kriteria 1, serta perkalian matriks antara Eigen vector pada pembobotan Sub Kriteria 2 dan normalisasi dari hasil interpretasi Sub Kriteria 2. Hasil ini akan mempengaruhi data pada normalisasi dari hasil interpretasi Kriteria. Setelah di temukan nilai Sub Kriteria 1 dan Sub Kriteria 2, maka nilai tersebut digunakan sebagai nilai Kriteria Kondisi Gedung (C6) dan Jarak dari Pusat Keramaian (C7) pada tabel hasil normalisasi data alternatif. Dengan mengalikan normalisasi dari hasil interpretasi data alternatif dengan Eigen vector bobot kriteria, maka akan dihasilkan nilai final, dan dapat diurutkan untuk menjadi ranking. Dan proses SPK penentuan lokasi ATM menggunakan AHP dan SAW telah 
mendapatkan keluaran berupa urutan rekomendasi untuk menentukan lokasi ATM. Hasil perhitungan dapat dilihat pada tabel yang telah di urutkan berdasarkan nilai rekomendasi terbaik (higher is better).

Pengujian dilakukan dengan cara membandingkan antara hasil rekomendasi berdasarkan perhitungan AHP dan SAW dengan realisasi Deployment ATM tahun 2017. Pengujian dilakukan dengan confusion matrix, dan akan didapatkan hasil berupa error rate, accuracy, sensitivity dan specifity.

\section{HASIL DAN PEMBAHASAN}

\subsection{Hasil Uji Signifikansi}

Berdasarkan uji validitas dan signifikansi dari hasil kuisioner terhadap 30 responden, pada pengujian kriteria, terdapat 7 variabel, untuk sub kriteria 1 terdapat 4 variabel, dan untuk sub kriteria 2 terdapat 8 variabel.

Tabel 3. Perbandingan signifikansi antar kriteria

\begin{tabular}{|c|c|c|c|c|c|c|c|}
\hline \multirow[t]{2}{*}{ Kriteria } & \multicolumn{7}{|c|}{ Signifikansi Variabel } \\
\hline & $\mathrm{C} 1$ & $\mathrm{C} 2$ & $\mathrm{C} 3$ & $\mathrm{C} 4$ & $\mathrm{C} 5$ & C6 & C7 \\
\hline C1 & & & $\checkmark$ & & & & \\
\hline \multicolumn{8}{|l|}{ C2 } \\
\hline C3 & $\checkmark$ & & & $\checkmark$ & $\checkmark$ & & \\
\hline C4 & & & $\checkmark$ & & $\checkmark$ & & \\
\hline C5 & & & $\checkmark$ & $\checkmark$ & & & \\
\hline \multicolumn{8}{|l|}{ C6 } \\
\hline C7 & & & & & & & \\
\hline
\end{tabular}

Untuk uji signifikansi pada kriteria C1, nilai C3 sebesar 0,042 $(\mathrm{p}<0,05)$, artinya variabel $\mathrm{C} 3$ berpengaruh signifikan terhadap $\mathrm{C} 1$. Uji signifikansi pada kriteria $\mathrm{C} 3$, variabel yang berpengaruh signifikan adalah C1 (0,042), C4 (0,019), dan C5 (0,001). Uji signifikansi pada kriteria $\mathrm{C} 4$, variabel yang berpengaruh signifikan adalah C3 (0,019), dan C5 (0,000). Uji signifikansi pada kriteria $\mathrm{C} 5$, variabel yang berpengaruh signifikan adalah $\mathrm{C} 3$ (0,001), dan C4 (0,000). Sedangkan untuk kriteria C2, C6, dan C7 tidak terdapat variabel yang signifikan mempengaruhi kriteria tersebut. Sehingga untuk kriteria yang teruji signifikansi hanya kriteria C1, C3, C4 dan C5.

\subsection{Hasil Implementasi Data}

Terdapat 3 kasus berbeda yang diujikan pada SPK ini berdasarkan pembobotan yang ditentukan narasumber. Berikut disajikan 40 hasil ranking teratas dari nilai rekomendasi ATM berdasarkan rata-rata nilai ketiga kasus yang telah diujikan yang tidak teruji signifikansi dan nilai rekomendasi ATM yang teruji signifikansi yang diurutkan pada rangking nilai rekomendasi lokasi ATM teruji signifikansi pada gambar 2 .

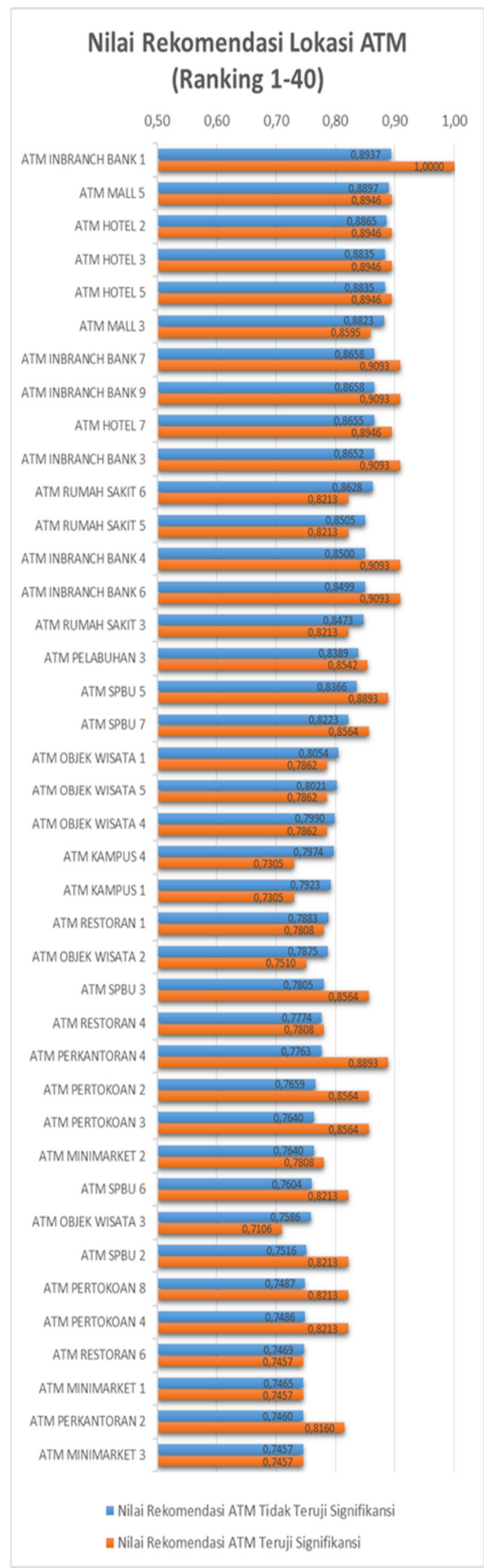

Gambar 2. Grafik Perbandingan Nilai Hasil Rekomendasi Lokasi ATM yang Tidak Teruji Signifikansi dengan yang Teruji Signifikansi

\subsection{Hasil Implementasi Perangkat Lunak}

Hasil perhitungan SPK penentuan lokasi ATM dengan metode AHP dan SAW ini juga diterapkan pada perangkat lunak berbasis web, dengan hasil yang sama dengan perhitungan manual. 
Berikut ditampilkan hasil implementasi perangkat lunak pada perhitungan kasus 1 pada gambar 3 dan gambar 4 .

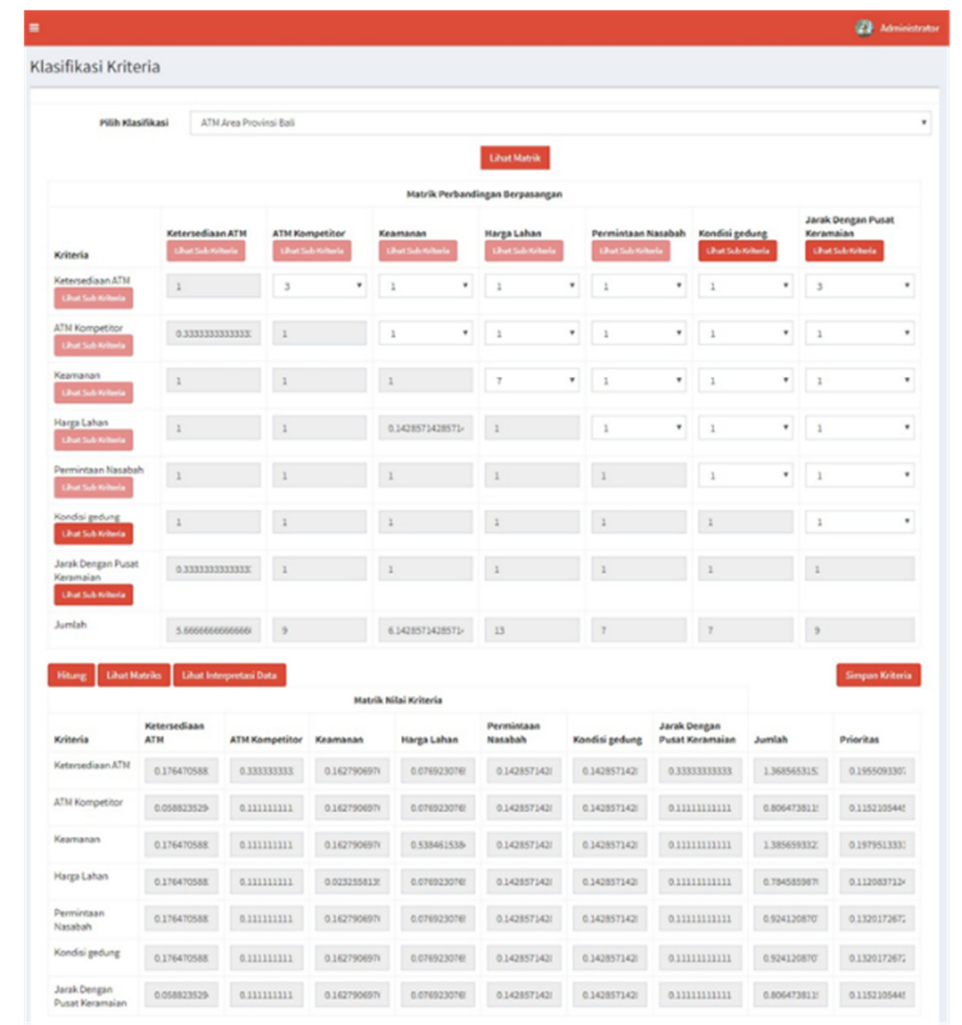

Gambar 3. Hasil Implementasi Perangkat Lunak (Kasus 1) untuk Pembobotan antar Kriteria

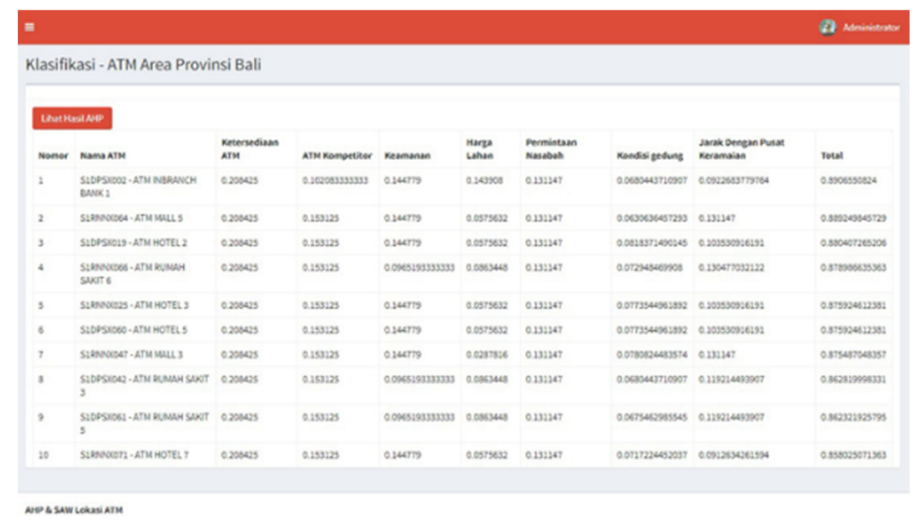

Gambar 4. Hasil Implementasi Perangkat Lunak (Kasus 1) untuk Perangkingan

\subsection{Pembahasan Hasil Penelitian}

Dari 76 data alternatif, hanya terdapat 38 realisasi pada deployment tahun 2017. Pengujian akurasi hasil perankingan pada SPK penentuan lokasi ATM menggunakan AHP dan SAW dilakukan dengan confusion matrix pada kriteria yang tidak teruji signifikansi, yang dapat dilihat pada tabel 5, dan setelah dilakukan klasifikasi, dapat dihitung nilai Error Rate (ERR), Accuracy (ACC), Recall/ Sensitivity/ True Positive Rate (TPR), Specificity/True Negative Rate (TNR), Precision/False Negative Rate (FNR) dan False Positive Rate (FPR).

Terdapat 5 lokasi ATM yang termasuk False Negative yaitu ATM MINIMARKET 3 (SIDPSX022), ATM PERKANTORAN 2 (S1RNNX028), ATM MINIMARKET 6 (S1DPSX048), ATM PERTOKOAN 5 (S1SGRX057) dan ATM MINIMARKET 8 54 Gede Surya Mahendra
(S1DPSX065). Selain itu terdapat 5 lokasi ATM yang termasuk False Positive yaitu ATM OBJEK WISATA 2 (S1RNNX012), ATM SPBU 2 (S1DPSX015), ATM OBJEK WISATA 3 (S1SGRX027), ATM PERTOKOAN 4 (S1SGRX044), dan ATM RESTORAN 6 (S1DPSX069).

Untuk pengujian akurasi hasil perankingan pada SPK penentuan lokasi ATM menggunakan AHP dan SAW dilakukan dengan confusion matrix pada kriteria yang teruji signifikansi, yang dapat dilihat pada tabel 6. Terdapat 3 lokasi ATM yang termasuk False Negative yaitu ATM KAMPUS 1 (S1DPSX003), ATM KAMPUS 4 (S1DPSX059), dan ATM MINIMARKET 8 (S1DPSX065). Selain itu terdapat 3 lokasi ATM yang termasuk False Positive yaitu ATM OBJEK WISATA 2 (S1RNNX012), ATM SPBU 2 (S1DPSX015), dan ATM PERTOKOAN 4 (S1SGRX044).

https://doi.org/10.25077/ TEKNOSI.v5i1.2019.49-56 
Tabel 4. Confusion Matrix Antara Hasil Rekomendasi dan Realisasi Deployment 2017 dengan Kriteria dan Sub Kriteria yang Tidak Teruji Signifikansi

\begin{tabular}{cccc}
\hline \multirow{2}{*}{ Confusion Matrix } & \multicolumn{2}{c}{ Predicted Class } \\
\cline { 2 - 4 } & & Positive & Negative \\
\hline Actual Class & Positive & (True & (False \\
& & Positive) & Negative) \\
& & 33 & 5 \\
\cline { 2 - 4 } & Negative & (False & (True \\
& & Positive) & Negative) \\
& & 5 & 38
\end{tabular}

Dengan penelitian lebih lanjut terhadap kondisi False Negative dan False Positive tersebut, diketahui bahwa terdapat penyebab seperti sengketa pemilik lahan/ gedung ATM, kondisi lokasi rawan bencana, relokasi akibat perjanjian dengan pemilik lahan serta relokasi akibat serah terima pengelolaan mesin ATM antar cabang.

Berdasarkan pengujian pada hasil implementasi data dan implementasi perangkat lunak, didapatkan hasil akurasi klasifikasi SPK penentuan lokasi ATM menggunakan AHP dan SAW sebesar $86,84 \%$, dengan TPR sebesar $86,84 \%$, TNR sebesar $88,37 \%$, dan ERR sebesar 7,89\%.
Tabel 5. Confusion Matrix Antara Hasil Rekomendasi dan Realisasi Deployment 2017 dengan Kriteria dan Sub Kriteria yang Teruji Signifikansi

\begin{tabular}{|c|c|c|c|}
\hline \multicolumn{2}{|c|}{ Confusion Matrix } & \multicolumn{2}{|c|}{ Predicted Class } \\
\hline & & Positive & Negative \\
\hline \multirow[t]{6}{*}{ Actual Class } & Positive & (True & (False \\
\hline & & Positive) & Negative) \\
\hline & & 35 & 3 \\
\hline & Negative & (False & (True \\
\hline & & Positive) & Negative) \\
\hline & & 3 & 35 \\
\hline
\end{tabular}

. Sedangkan ketika perhitungan dilakukan pada kriteria yang telah di uji signifikansi mendapatkan hasil akurasi klasifikasi SPK penentuan lokasi ATM menggunakan AHP dan SAW sebesar 92,11\%, dengan TPR sebesar 92,11\%, TNR sebesar 92,11\%, dan ERR sebesar 7,89\%. Terdapat peningkatan ACC sebesar 6,07\%, dan penurunan ERR hingga 40,05\% pada hasil rekomendasi lokasi ATM tidak teruji signifikansi dibandingkan dengan rekomendasi lokasi ATM teruji signifikansi. Kesimpulan yang diperoleh dari pengujian akurasi ini adalah bahwa AHP dan SAW dapat digunakan sebagai metode pada SPK penentuan lokasi ATM karena tingkat akurasinya yang baik, dan uji signifikansi dapat meningkatkan akurasi dari perhitungan SPK menggunakan metode AHP dan SAW.

\section{Perbandingan Hasil Confusion Matrix Nilai Rekomendasi ATM}

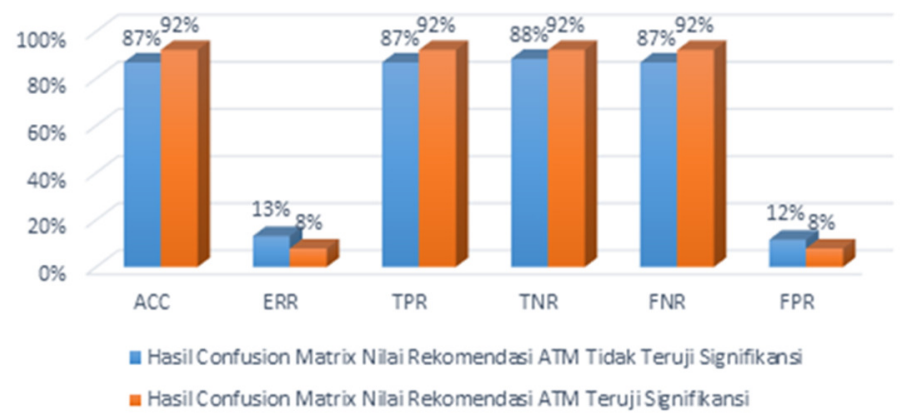

Gambar 5. Perbandingan Hasil Confusion Matrix Nilai Rekomendasi ATM

\subsection{Kendala Dalam Penelitian}

Dalam penelitian ini terdapat beberapa kendala yang dihadapi oleh peneliti. Dalam penentuan kriteria dan sub kriteria, masih tedapat beberapa kriteria dan sub kriteria yang belum tercakup dalam penelitian ini yang diakibatkan dari keterbatasan sumber literatur, keterbatasan pengetahuan ahli, serta keterbatasan dalam penggalian sumber permasalahan di lapangan. Hal ini dapat diatasi dengan cara memperbanyak studi literatur, meningkatkan kualitas dan kuantitas narasumber dan ahli, serta memperluas kajian permasalahan di lapangan. Kriteria dan sub kriteria yang perlu ditambahkan antara lain kepadatan nasabah/ penduduk, sengketa pemilik lahan/ gedung ATM, serta kondisi lokasi rawan bencana.
Dalam penilaian masing-masing kriteria dan sub kriteria juga mengalami kendala, karena penilaian terhadap suatu lokasi ATM sangat beragam berdasarkan kondisi strategis lingkungan. Dalam menilai ketersediaan ATM dan ATM Kompetitor pada radius tertentu dan harga lahan untuk daerah padat bangunan berbeda dengan daerah yang jumlah bangunannya sedikit. Dalam menilai keamanan memiliki kendala ketika petugas keamanan hanya ada dalam kurun waktu tertentu, mengakibatkan keraguan dalam penilaian kondisi keamanan. Dalam menilai permintaan nasabah, masih terdapat perbedaan antara permintaan nasabah perorangan dan nasabah korporat. Dalam hal penilaian ini dapat diatasi dengan instrumen penilaian yang lebih akurat atau dapat menggunakan fuzzy logic.

Terdapat peluang terjadinya konflik kepentingan dalam penentuan lokasi ATM. Dalam hal ini output dari SPK penentuan lokasi ATM ini hanyalah rekomendasi, dan keputusan tetap 
berada di tangan stakeholders. Hal ini dapat diminimalisir dengan kriteria permintaan nasabah yang mencakup permintaan nasabah dari segi perorangan ataupun pihak korporat.

\section{KESIMPULAN}

Rancang bangun SPK Penentuan Lokasi ATM menggunakan AHP dan SAW dapat diimplementasikan dan dilakukan analisis terhadap hasil rekomendasi dibandingkan dengan data realisasi deployment ATM dan dapat membantu pengambil keputusan dalam masalah penentuan lokasi ATM secara cepat dan mudah. Hasil pengujian yang dilakukan pada 76 kasus uji, dengan terealisasi sebanyak 38 kasus uji, menghasilkan 66 kasus uji yang sesuai dan 10 kasus yang tidak sesuai, dengan akurasi sebesar $86,84 \%$, dan setelah dilakukan uji signifikansi akurasi meningkat menjadi $92,11 \%$. SPK Penentuan Lokasi ATM menggunakan AHP dan SAW dapat digunakan di berbagai platform sistem operasi dan browser. Hasil rekomendasi penentuan lokasi ATM menjadi lebih objektif karena user tidak menentukan alternatif yang akan dipilih secara langsung. Penentuan pembobotan kriteria dan sub kriteria pada AHP sangat mempengaruhi hasil perhitungan ranking pada SAW

Agar memperoleh hasil yang lebih baik, diharapkan dalam merumuskan kriteria dan sub kriteria dapat mencari lebih baik dari studi literatrur, meningkatkan kualitas dan kuantitas narasumber, memperluas kajian permasalahan di lapangan, sehingga perlunya ditambah kriteria atau sub kriteria seperti kepadatan nasabah/ penduduk, kondisi sengketa pemilik lahan/ gedung ATM, serta kondisi lokasi rawan bencana. Untuk kriteria diharapkan untuk melakukan uji validitas, uji reabilitas dan uji signifikansi dari kriteria dan sub kriteria yang diperoleh dengan menggunakan kuisioner yang lebih baik dengan kualitas dan kuantitas narasumber yang lebih baik. Dalam penentuan narasumber setidaknya melibatkan berbagai pihak yang berhubungan dengan ATM, baik dari tingkat kantor pusat, kantor wilayah, kantor cabang, vendor dan pihak pelaksana. Penilaian terhadap masing-masing alternatif terhadap kriteria disempurnakan dengan memilih instrument penilaian yang lebih akurat atau menggunakan fuzzy logic. Selanjutnya, diharapkan daerah penelitian diperluas dan melakukan perhitungan dengan metode berbeda untuk mendapatkan hasil penelitian yang lebih baik dan lebih akurat..

\section{DAFTAR PUSTAKA}

[1] I. Rismawan, "Pertumbuhan Ekonomi Bali dan Nusa Tenggara Kategori Luar Biasa," Tribun Bisnis, 2016. [Online]. Available: http://www.tribunnews.com/bisnis/2016/02/29/pertumbuh an-ekonomi-bali-dan-nusa-tenggara-kategori-luar-biasa.

[2] G. D. G. Diyaksa, "EKSKLUSIF: Aksi Sindikat Internasional Menguras ATM di Indonesia," Liputan 6, 2017. [Online]. Available: http://news.liputan6.com/read/3104557/eksklusif-aksisindikat-internasional-menguras-atm-di-indonesia.

[3] H. Wibowo, "MADM-Tool: Aplikasi Uji Sensitivitas untuk Model MADM Menggunakan Metode Saw dan Topsis," Semin. Nas. Apl. Teknol. Inf. 2010 (SNATI 2010) ISSN 1907-5022 Yogyakarta, 19 Juni 2010, 2010.

[4] C. Kahraman, Fuzzy Multi Criteria Decision Making, Theory Application withRecent Documents. Istanbul: Springer., 2008.

56 Gede Surya Mahendra
[5] A. Afshari, M. Mojahed, and R. M. Yusuff, "Simple Additive Weighting approach to Personnel Selection problem," Int. J. Innov. Manag. Technol. Vol. 1, No. 5, December 2010 ISSN 2010-0248, vol. 1, no. 5, pp. 511515, 2010.

[6] M. H. Kutner, C. J. Nachtsheim, and J. Neter, Applied Linear RegressionModels, 4th ed. New York: McGraw-Hill Companies, Inc, 2004.

[7] S. et al Kusumadewi, Fuzzy Multi-Attribute Decision Making (FUZZY MADM). Yogyakarta: Graha Ilmu, 2006.

[8] Bramer, Principle of Data Mining. London: Springer, 2007.

[9] J. Han and M. Kamber, Data Mining: Concept and Techniques, Third Edition. Waltham: Morgan Kaufmann Publishers, 2012.

[10] F. Tscheikner-Gratl, P. Egger, W. Rauch, and M. Kleidorfer, "Comparison of multi-criteria decision support methods for integrated rehabilitation prioritization," Water (Switzerland), vol. 9, no. 2, 2017.

[11] E. N. S. Purnomo, S. W. Sihwi, and R. Anggrainingsih, "Analisis Perbandingan Menggunakan Metode AHP, TOPSIS, dan AHP-TOPSIS dalam Studi Kasus Sistem Pendukung Keputusan Penerimaan Siswa Program Akselerasi," J. ITSMART, vol. 2, no. 1, 2013.

[12] F. F. Zam zam, "Analisa Perbandingan Metode SAW dan WP dalam Mendukung Keputusan Penilaian Kinerja Dosen," Universitas PGRI Kediri, 2016.

[13] A. Setyawan, F. Y. Arini, and I. Akhlis, "Comparative Analysis of Simple Additive Weighting Method and Weighted Product Method to New Employee Recruitment Decision Support System (DSS) at PT. Warta Media Nusantara," Sci. J. Informatics, vol. 4, no. 1, 2017.

\section{BIODATA PENULIS}

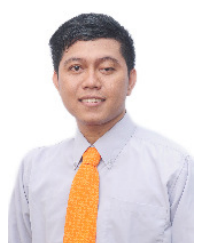

Gede Surya Mahendra, S.Pd., M.Kom. Lahir di Singaraja pada tahun 1990 dan menyelesaikan pendidikan dasar di SD Negeri 3 Banjar Jawa Singaraja, dan lulus pada tahun 2002. Kemudian, penulis melanjutkan di SMP Negeri 1 Singaraja dan lulus pada tahun 2005. Pada tahun 2008, penulis lulus dari SMA Negeri 1 Singaraja dan melanjutkan ke Program S1 Jurusan Pendidikan Teknik Informatika di Universitas Pendidikan Ganesha dan lulus pada tahun 2013. Tahun 2016 melanjutkan di Program Pascasarjana Program Studi Ilmu Komputer di Universitas Pendidikan Ganesha dan lulus pada tahun 2018.

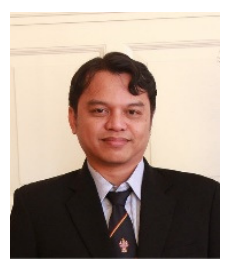

Kadek Yota Ernanda Aryanto, S.Kom., M.T., Ph.D. Lahir di Singaraja pada tahun 1978 dan merampungkan sekolah dasar hingga menengah atas di tanah kelahiran. Melanjutkan studi pada tingkatan sarjana pada tahun 1996 di Jurusan Teknik Informatika, Institut Teknologi Sepuluh Nopember (ITS) Surabaya. Kemudian melanjutkan studi pada strata magister di Jurusan Teknik Elektro ITS Surabaya tahun 2007 dengan bidang peminatan Jaringan Cerdas Multimedia. Mengakhiri studi dengan pujian dan memperoleh gelar Magister Teknik (M.T.). Tepat setelah menyelesaikan studi S2, mendapat panggilan untuk melanjutkan studi serta memperoleh beasiswa di University of Groningen pada tahun 2009 dan berhasil memperoleh gelar Ph.D dalam bidang keahlian Informatika/Ilmu Komputer khususnya dalam Informatika Kesehatan. 